\title{
Determinan Market Share Perbankan Syariah di Indonesia
}

\author{
Eliana ${ }^{1^{*}}$, Nazri Zarman ${ }^{2}$, Ismuadi ${ }^{3}$, Intan Novia Astuti ${ }^{4}$, Ayumiati $^{5}$ \\ 1, 2, ${ }^{4}$ Sekolah Tinggi IImu Ekonomi Sabang (STIES) Banda Aceh \\ ${ }^{3,5}$ Fakultas Ekonomi dan Bisnis Islam (FEBI) UIN Ar-Raniry \\ 1eliana@stiesabang.ac.id, ²nasrizarman@stiesabang.ac.id, 3ismuadi@ar-raniry.ac.id, \\ ${ }^{4}$ Intan@stiesabang.ac.id, 5ayumiati@ar-raniry.ac.id \\ *Penulis Korespondensi
}

\begin{abstract}
Sharia banking is currently very popular with the Indonesian people, so to prepare for this increasingly selective business competition, Islamic Commercial Banks are required to improve their company performance so that investors are attracted to invest. This study aims to determine the effect of BOPO, ROA, NPF, and DPK on the market share of Islamic banking in Indonesia. The samples used were BUS and UUS with 52 data. Multiple linear regression is used as an analysis technique to produce a detailed description of the relationship of each variable used. The regression results tell that BOPO and DPK have no significant effect on market share, while ROA and NPF have a positive and significant effect on market share in Islamic banking in Indonesia.
\end{abstract}

Keywords: Market Share; BOPO; ROA; NPF; DPK

\begin{abstract}
Abstrak
Perbankan syariah saat ini sudah sangat digemari oleh masyarakat indonesia sehingga untuk menyiapkan persaingan bisnis yang semakin selektif ini menuntutbus untuk meningkatkan kinerja perusahaannya sehingga menyebabkan investor menarik untuk menanamkan modal. Penelitian ini bertujuan untuk mengetahui pengaruh BOPO, ROA, NPF dan DPK terhadap market share perbankan Syariah di Indonesia. Sampel yang digunakan adalah BUS dan UUS dengan jumlah 52 data. Regresi linier berganda dipakai sebagai tekni analisa untuk menghasilkan gambaran yang terperinci hubungan tiap variabel yang digunakan. Hasil regresi menceritakan bahwa BOPO dan DPK tidak berpengaruh signifikan terhadap market share,sedangkan ROA dan NPF berpengaruh positif dan signifikansi terhadap market share di perbankan Syariah di Indonesia.
\end{abstract}

Kata kunci: Market Share; BOPO; ROA; NPF; DPK

\section{Cara Mengutip:}

Eliana, Zarman N., Ismuadi, Astuti, I. N. , Ayumiati (2020). Determinan Market Share Perbankan Syariah di Indonesia. Esensi: Jurnal Bisnis dan Manajemen. Vol. 10 (2): 199-204. DOI: https://doi.org/10.15408/ess. v10i2.18601 


\section{PENDAHULUAN}

Perbankan syariah yakni suatu lembaga keuangan syariah yang memiliki kontribusi utama bagi perekonomian suatu pemerintahan. Salah satu bentuk upaya pemerintah dalam mendukung pengembangan perbankan syariah dimulai dari dikeluarkannnya UU Nomor 21 Thn 2008 tentang perbankan syariah. strategis yang lain dapat dilakukan pemerintah dalam memberi dukungan memberikan izin kepada bank konven (BUK) untuk membuka Kantor Cabang Unit Usaha syar'yah atau mengkonversi sebuah bank konvensional menjadi bank syariah.

Dalam perkembangannya secara market share, industri keuangan syariah nasional masih belum mendekati tingkat yang diinginkan dibanding dengan aset keuangan syariah secara global. Walaupun Indonesia telah meraih peringkat terbesar sembilan di dunia dengan asset sekitar USD 66,2 milyar dihitung sejak Desember 2016. Selain Indonesia telah penghargaan dan pengukuhan dari dunia internasional bersama dengan UAE, Arab Saudi, Malaysia dan Bahrain (OJK, 2020).

Salah satu tantangan adalah sulitnya memperluas market share sehingga menjadi daya tarik publik, pemerintah maupun masyarakat. Sumber data yang diperoleh dari OJK untuk akhir Juni 2018, market share keuangan syariah sempat mencapai 8,47\% dari total asset keuangan Indonesia. Ini peroleh dari kontribusi Perbankan Syariah sebesar 5,7\%, Industri Keuangan Non Bank syariah sebesar 4,69\% dan Pasar Modal Syariah sebesar 15,28\%, hingga awal 2020 market share perbankan syariah nasional mampu mencapai 5,99\%. Hal ini sesuai dengan data statistik market share bank syariah di Indonesia yang terpublis oleh OJK.

Tabel 1 Pertumbuhan Aset dan Market Share Perbankan Syariah

\begin{tabular}{ccccccc}
\hline Indikator & Satuan & $\mathbf{2 0 1 6}$ & $\mathbf{2 0 1 7}$ & $\mathbf{2 0 1 8}$ & $\mathbf{2 0 1 9}$ & $\mathbf{2 0 2 0}$ \\
\hline Aset & Miliar Rupiah & 365,6 & 435,0 & 489,7 & 499,3 & 536,60 \\
Market share & $\%$ & 5,55 & 5,78 & 5,96 & 5,95 & 5,99 \\
\hline
\end{tabular}

Sumber: SPS (OJK, 2020)

Dari tabel 1, diketahui bahwa total asset perbankan syariah mengalami kenaikan sejak lima tahun terakhir, hal ini memberi pengaruh terhadap market share dimana tingakat rasio market share dari beberapa tahun terakhir memperoleh peningkatan, pada Maret 2020 market share bisa menjangkau 5,99\% dari total aktivaperbankan nasional

Berdasarkan data Statistik PS menunjukkan pertumbuhan aset, dana pihak ketiga dan pembiayaan terus menurun. Hal ini dapat dilihat dari Grafik 1. 
Gambar 1 Pertumbuhan Asset, PYD dan DPK Perbankan Syariah

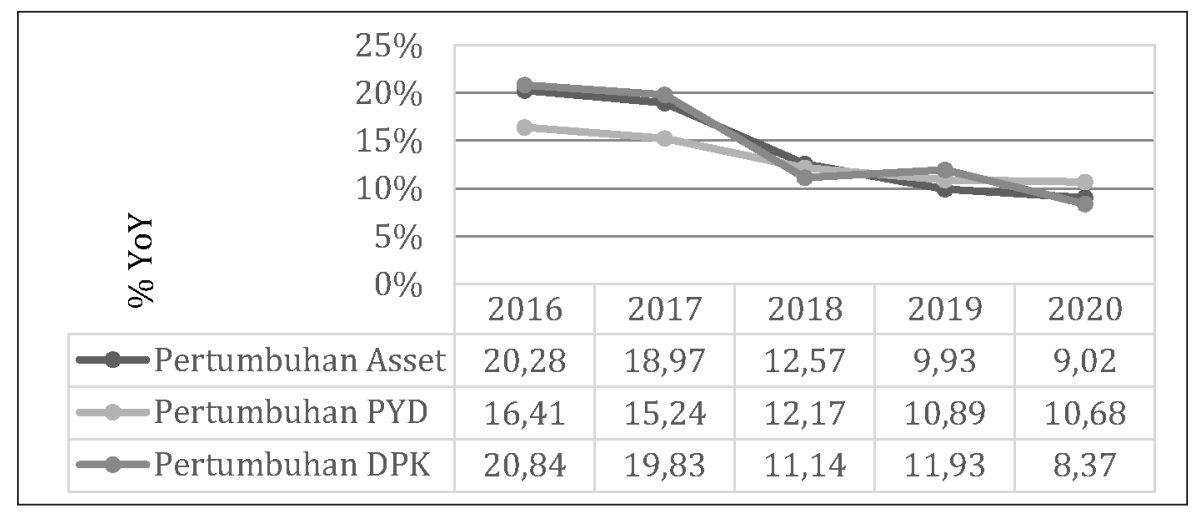

Sumber: Otoritas Jasa Keuangan (2019)

Untuk mendukung peningkatan perkembangan pertumbuhan perbankan syariah dibutuhkan kinerja yang baik dari bank syariah baik itu BUS, UUS maupun BPRS. Untuk mengukur kinerja bank syariah dengan memeriksadari annual report keuangan bank itu sendiri melalui beberapa indikator diantaranya Biaya Operasional Pendapatan Operasional (BOPO), ROA, FDR, CAR dan Non Performance Finance (NPF).

Tabel 2 Data Kinerja Perbankan Syariah 2016-2020

\begin{tabular}{ccccccc}
\hline Indikator & Satuan & $\mathbf{2 0 1 6}$ & $\mathbf{2 0 1 7}$ & $\mathbf{2 0 1 8}$ & $\mathbf{2 0 1 9}$ & $\mathbf{2 0 2 0}$ \\
\hline BOPO & $\%$ & 96,22 & 94,91 & 89,18 & 84,45 & 83,62 \\
ROA & $\%$ & 0,63 & 0,63 & 1,28 & 1,73 & 1,88 \\
FDR & $\%$ & 85,99 & 79,61 & 78,53 & 77,91 & 77,90 \\
CAR & $\%$ & 16,63 & 17,91 & 20,39 & 20,59 & 20,27 \\
NPF & $\%$ & 4,42 & 4,76 & 3,26 & 3,23 & 3,46 \\
\hline
\end{tabular}

Sumber: Statistik Perbankan Syariah (OJK, 2020).

Berdasarkan Tabel 2, dapat dilihat nilai rasio BOPO cenderung mengalami penurunan dari 4 tahun belakangan, yang berarti perbankan syariah telah mampu meminimalisir biaya operasionalnya dengan efisien dan juga mengelola sumber daya nya dengan baik. Begitu juga dengan kelancaran pengembalian terhadap harta perbankan syariah tahun 2016-2020 mengalami peningkatan tiap tahunnya. Kemudian pada sisi pembiayaan mengalami penurunan sejak empat tahun terakhir, nilai rasio menunjukkan penyaluran pembiayaan oleh perbankan syariah mengalami peningkatan namun tidak signifikan. Dari sisi pengembalian modal perbankan syariah mengalami peningkatan sejak lima tahun terakhir, dimana nilai rasio CAR sateiap tahunnya meningkat. Oleh karena itu, dapat disimpulkan bahwa nilai NPF dari tahun 2016-2020 mengalami penurunan, menunjukkan bahwa perbankan syariah selama rentang waktu tersebut telah mengalami peningkatan dari segi kinerja, sehingga membantu dalam meningkatkan market share. penelitian ini dilakukan untuk menguji determinan market share perbankan syariah melalui kinerja keuangan yaitu Biaya Operasional dan Pendapatan Operasional, Return on Assets, Non 
Performance Financing dan Dana Pihak Ketiga selama rentang waktu Januari 2016 sampai dengan April 2020.

$\mathrm{H}_{1}$ : BOPO, ROA, NPF dan DPK secara simultan berpengaruh positif terhadap Market share di Perbankan Syariah

$\mathrm{H}_{2}$ : Bopo berpengaruh positif terhadap Market share di Perbankan Syariah

$\mathrm{H}_{3}$ : ROA berpengaruh positif terhadap Market share di Perbankan Syariah

$\mathrm{H}_{4}$ : NPF berpengaruh positif terhadap Market share di Perbankan Syariah

$\mathrm{H}_{5}$ : DPK berpengaruh positif terhadap Market share di Perbankan Syariah

\section{METODE}

Dalam penelitian ini populasi yang digunakan adalah seluruh Bank Umum Syariah dan Unit Usaha Syariah yang memiliki laporan keuangan yang telah di publikasi secara resmi selama periode 2016-2020.

Serta 20 UUS yang meliputi BTN, BPD DKI, Yogyakarta, Jawa Tengah, Jawa Timur, Jambi, Sumatera Utara, Sumatera Barat, Riau, Sumatera Selatan dan Bangka Belitung, Kalimantan Selatan, Kalimantan Barat, Kalimantan Timur, Sulawesi Selatan dan Barat, BDI, Permata , CIMB Niaga, OCBN NISP, Sinarmas dan Maybank .

\section{Sampel}

Sampel yang digunakan adalah laporan keuangan seluruh anggota populasi yang terdapat pada data statistik perbankan syariah yang dikeluarkan oleh OJK dari 2016 sampai 2020. Jadi total data yang digunakan sebanyak 52 data.

Metode analisa yang digunakan dalam penelitian ini adalah ada uji kulitas dan uji hipotesa, uji kuliatas data digunakan metode regresi linier berganda menguji pengaruh variabel yang saling terikat satu sama lain.Kemudian perlu diketahui bukan variabel $\mathrm{x}$ (independen) saja yang mempengaruhi variabel Y (dependen) tetapi ada variabel lain yang bisa mempengaruhi dalam mengobservasi yaitu variabel error. Untuk menghasilkan nilai parametric yang shahih maka perlu dilakukan uji asumsi klasik diantaranya uji normalitas, multikolinearitas, dan heteroskedastisitas. Dalam pengujian hipotesis dilakukan dengan metode regresi linear berganda, uji t, Uji F, dan koefisien determinasi.

\section{HASIL DAN PEMBAHASAN}

\section{Pengaruh BOPO terhadap Market Share}

Secara parsial BOPO tidak berpengaruh signifikan terhadap market share perbankan syariah dengan nilai sig sebesar $0.097>$ dari 0,05 yang berarti bahwa apabila BOPO meningkat maka pendapatan perusahaan akan menurun.jika kegiatan opersional perusahaan dilakukan dengan efisien artinya rasio BOPO lebih rendah maka penghasilan yang didapat oleh perbankan syariah akan tinggi. Besarnya rasio BOPO dikarenakan biaya dana yang dihimpun lebih tinggi dan sehingga pendapatan bunga akan rendah, yang menyebakan semakin kecil atau menurun kinerja keuangan. 
Perusahaan yang baik kinerjanya adalah perusahaan yang bisa menekankan biaya operasional, ini menggambarkan bahwa jumlah pendapatan yang dihasilkan masih berada angka maksimum walaupun sudah dikurangi dengan penegeluaran baiaya operasional. Tingginya nilai pendapatan yang diperoleh perusahaan secara optimal akan membuat perusahaan mampu bersaing di pangsa pasar internasional. Penelitian sejalan dengan Ponco (2010) yang menyatakan bahwa BOPO berpengaruh negatif dan tidak signifikan terhadap kinerja keuangan perbankan.

\section{Pengaruh ROA Terhadap Market Share}

Hasil pengujian secara parsial menerangkan ROA berpengaruh positif signifikan terhadap MS Perbankan Syariah periode 2016-2020. Dapat diartikan bahwa semakin tinggi persentase ROA akan memberikan peningkatan pada ratio market share. Nilai sig. ROA yang didapatkan pada penelitian ini sebesar 0,047 lebih kecil dari 0,05 $(\alpha)$, sehingga $H_{0}$ ditolak $H_{a}$ diterima. Artinya makin tingginya tingkat profitabilitas suatu bank akan memberikan dampak yang positif, sehingga kepercayaan masyarakat lebih banyak untuk menempatkan dananya pada bank tersebut. Dengan demikian semakin besar ROA suatu bank semakin besar tingkat keuntungan yang dicapai bank sehingga semakin baik kinerja dan posisi pasar bank tersebut. ini sejalan dengan penelitian yang dilakukan oleh Saputra (2014) dimana ROA memberi pengaruh positif signifikan terhadap market share, penelitian yang dilakukan oleh Purboastusi, Anwar dan Suryahani (2015) mengungkapkan bahwa ROA memberikan pengaruh positif terhadap peningkatan market share, hal ini juga didukung oleh penelitian yang dilakukan Virawan (2017) menyimpulkan bahwa ROA memberikan pengaruh signifikan terhadap market share.

\section{Pengaruh NPF Terhadap Market Share}

Secara parsial menunjukkan bahwa NPF berpengaruh positif signifikan terhadap market share Perbankan Syariah periode 2016-2020. Nilai sig. NPF yang didapat dari pengujian penelitian sebesar 0,000 lebih kecil dari 0,05 $(\alpha)$, sehingga $H_{0}$ ditolak $H_{a}$ diterima. Hal ini terjadi karena rata-rata nilai NPF BUS dan UUS selama lima tahun terakhir sebesar 3,8\% dimana masih dibawah dalam batas maksimum tingkat NPF 5\% yang telah ditetapkan oleh Bank Indonesia. Sehingga dapat dilihat dari segi NPF perbankan syariah mampu mengatasi dengan baik yang memberikan dampak pada kinerja perbankan syariah semakin baik dan memperkuat posisi pasar perbankan syariah selama lima tahun terakhir.

Dalam hal ini sejalan dengan penelitian yang dilakukan oleh Purboastusi, Anwar dan Suryahani (2015) menyatakan NPF mempengaruhi positif signifikan terhadap peningkatan market share, namun bertolak belakang dengan hasil yang diperoleh oleh Saputra (2014) menyatakan bahwa NPF berpengaruh negatif terhadap peningkatan market share, akan tetapi pada penelitian Rahman (2016) menyatakan bahwa NPF memberikan pengaruh positif terhadap market share secara jangka panjang.

\section{Pengaruh DPK Terhadap Market Share}

Hasil pengujian menjelaskan DPK tidak berpengaruh signifikan terhadap market share Perbankan Syariah periode 2016-2020. Nilai sig. yang diperoleh DPK sebesar 0,067 
lebih besar dari 0,05 $(\alpha)$ dapat disimpulkan bahwa variabel DPK tidak memberi pengaruh terhadap peningkatan market share Perbankan Syariah. Hal ini terjadi karena tingkat persentase jumlah DPK selama lima tahun terakhir mengalami penurunan sebesar 12,47\%, dimana pada tahun 2016 jumlah DPK mampu mencapai sebesar 20,84\%, sehingga DPK tidak memberikan pengaruh yang signifikan dalam meningkatkan market share perbankan syariah. Hasil penelitian yang didapat memang bertolak belakang dengan teori yang ada, dimana Virawan (2017) mengungkapkan bahwa DPK memberikan pengaruh positif terhadap market share. Hal ini disebabkan karena tingkat jumlah DPK selama periode penelitian virawan meningkat secara signifikan, sehingga DPK dapat memberikan pengaruh terhadap peningkatan market share

\section{SIMPULAN}

Simpulan yang dapat ditarik bahwa BOPO, ROA, NPF dan secara simultan berpengaruh terhadap MS. BOPO dan DPK secara parsial tidak berpengaruh signifikan terhadap market share sedangkan ROA dan NPF berpegaruh positif dan signifikan terhadap MS di perbankan syariah. Saran untuk pihak manajemen bank dapat mempertahankan dan memperbaiki kinerja operasional bank. Sehingga dapat meningkatkan ratio market share setiap tahunnya.

\section{PUSTAKA ACUAN}

Otoritas Jasa Keuangan. (2020). Roadmap Perbankan Syariah Indonesia 2015-2019.

Ponco, Budi.(2010). Analisis Pengaruh CAR, NPL, BOPO, NIM dan LDR terhadap ROA (Studi Kasus Pada Perusahaan Perbankan yang Terdaftar di Bursa EfekIndonesia). Tesis. Universitas Diponegoro Semarang.

Purboastusi, Anwar, Suryani. (2015). Pengaruh Indikator Utama Perbankan Terhadap Pangsa Pasar Perbankan Syariah. Jejak: Journal of Economics and Policy, Vol.8.

Rahman, Aulia. (2016). Analisis Faktor-Faktor yang Mempengaruhi Market Share Bank Syariah. Jurnal Analytica Islamica, Vol.5, No.2.

Saputra, Bambang. (2014). Faktor-Faktor Keuangan yang Mempengaruhi Market Share Perbankan Syariah di Indonesia. Jurnal Akuntablitas, Vol VII, No 2. Halaman:123-131

Virawan, Adivia. (2017). Faktor-Faktor Yang Mempengaruhi Perlambatan Pertumbuhan Market Share Perbankan Syariah di Indonesia. 